


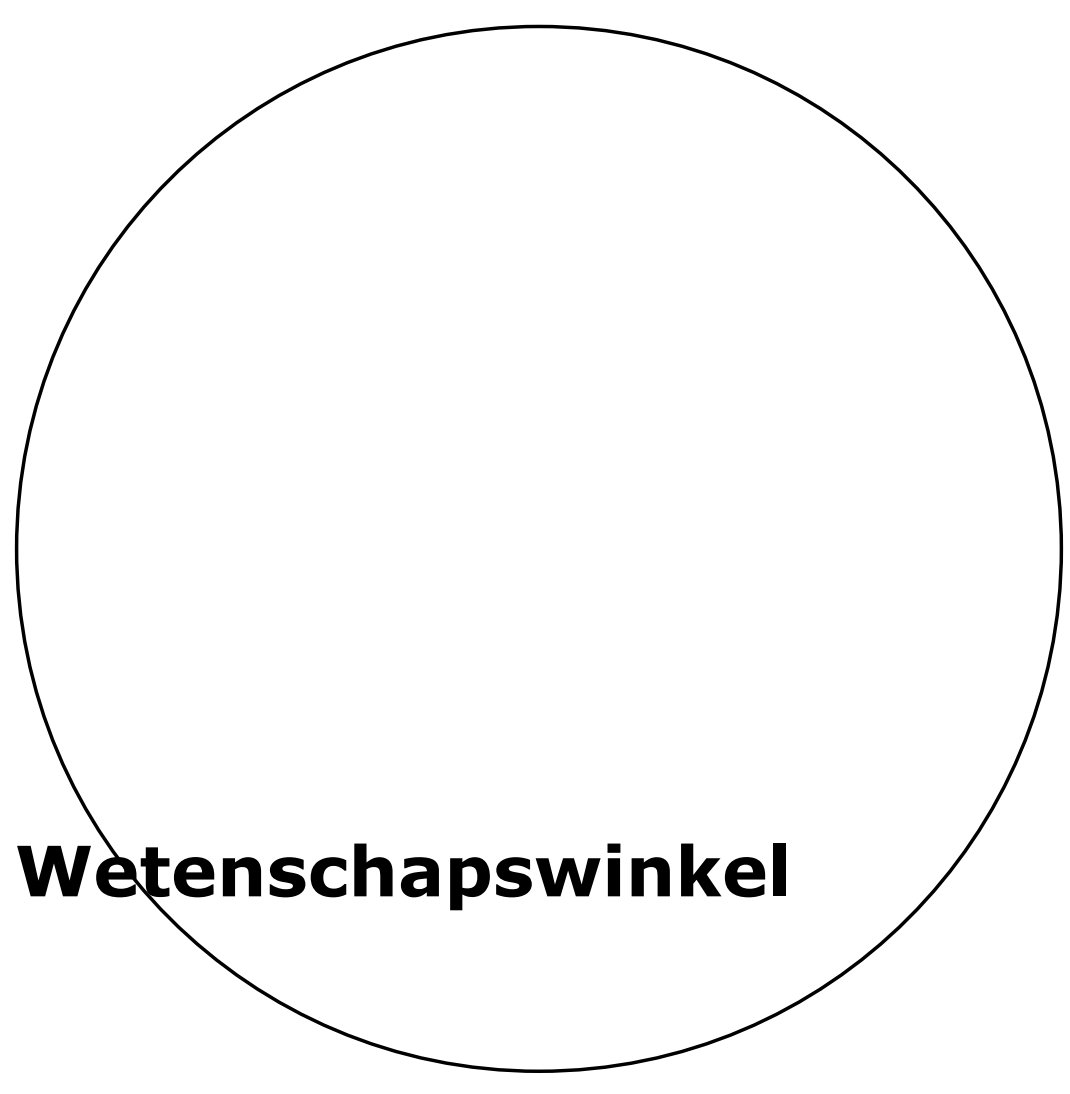

\section{Zin in landbouw en zorg}

Diepere drijfveren van zorgboeren en hoe die tot uiting komen in hun praktijken Judith Westerink, Marjolein Elings, Nona De Kloe-Bouwman, Naomi Slikboer 


\section{Begeleidingscommissie:}

Wouter Joop en Truida de Raaf (Stichting Omslag)

IJsbrand Snoeij (Zorgboerderij 't Paradijs)

Ina Horlings (Wageningen University \& Research/ Rijksuniversiteit Groningen)

Derk Klein Bramel +

Gerard Straver (Wetenschapswinkel Wageningen University \& Research)

Wij willen Sander Hoogendam hartelijk bedanken voor het ter beschikking stellen van zijn data

Publicatienummer 354

DOI $10.18174 / 503205$

ISBN 978-94-6395-165-4

De foto's in deze brochure zijn niet gemaakt op de boerderijen in deze studie. 


\section{Inhoud}

$\begin{array}{ll}\text { Woord vooraf } & 7\end{array}$

Inleiding $\quad 9$

Vraag van Stichting Omslag en zorgboerderij 't Paradijs 9

Eerder onderzoek naar waarden en drijfveren van zorgboeren 10

$\begin{array}{lr}\text { Onderzoeksvragen } & 10\end{array}$

Raamwerk en werkwijze
R

Waarden en drijfveren in de case studies 15

De Ander/ de Omgeving (horizontale verbinding) 16

$\begin{array}{ll}\text { De Uitdaging (voor jezelf) } & 17\end{array}$

De Levensstijl (dynamische verbinding) 17

$\begin{array}{lr}\text { De Essentie (verticale verbinding) } & 18\end{array}$

Relaties tussen drijfveren en waarden 19

$\begin{array}{ll}\text { Drijfveren en waarden in de praktijk } & 21\end{array}$

$\begin{array}{lr}\text { Hoe de boeren dat zien } & 21\end{array}$

Wat deelnemers en medewerkers herkennen $\quad 22$

$\begin{array}{lr}\text { Vormgeving van de plek } & 22\end{array}$

$\begin{array}{ll}\text { Praten over drijfveren en waarden } & 25\end{array}$

$\begin{array}{lr}\text { Literatuur } & 26\end{array}$ 


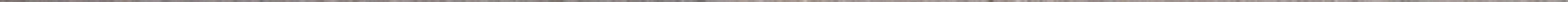

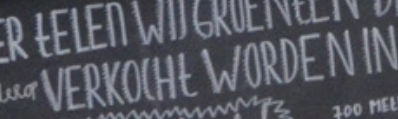

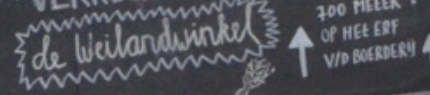




\title{
Woord vooraf
}

\author{
Beste lezer,
}

Met een beetje trots maar vooral dankbaarheid presenteren wij u deze brochure over een onderzoeksproces naar de drijfveren van zorgboeren en hoe deze in hun werkpraktijk zichtbaar worden. Een onderwerp wat naar onze mening essentieel is voor inspiratie in de sector, maar ook gemakkelijk een te filosofisch karakter krijgt.

De trots betreft vooral het zichtbaar worden van de systematische verkenning van deze drijfveren in concrete waarden. De dankbaarheid (-die overigens groter is dan onze trots-), gaat uit naar de onderzoekers en de studenten die ons hielpen het onderwerp in beeld te krijgen.

Naar onze overtuiging heeft de samenleving behoefte aan inspiratie, zorgboeren zijn daarop geen uitzondering. Wél spelen zorgboerderijen dikwijls een belangrijke rol in het hervinden van inspiratie; niet alleen bij de zorgvragers die zij ontvangen maar bij een wijde kring mensen er omheen.

Op een zorgboerderij wordt inspiratie zichtbaar! Dát gegeven maakt ons bewust van de noodzaak om hier over met collega's van gedachten te wisselen en elkaar te inspireren. Niet alleen het Wat en het Hoe van de dingen doen ertoe, maar zeker ook het Waarom. Niet om te onderwijzen of te beleren, maar om te inspireren. Deze brochure is voor ons een mijlpaal waarop we kunnen verder bouwen. Hartelijk dank daarvoor.

IJsbrand Snoeij (Zorgboerderij 't Paradijs)

Wouter Joop (Stichting Omslag) 


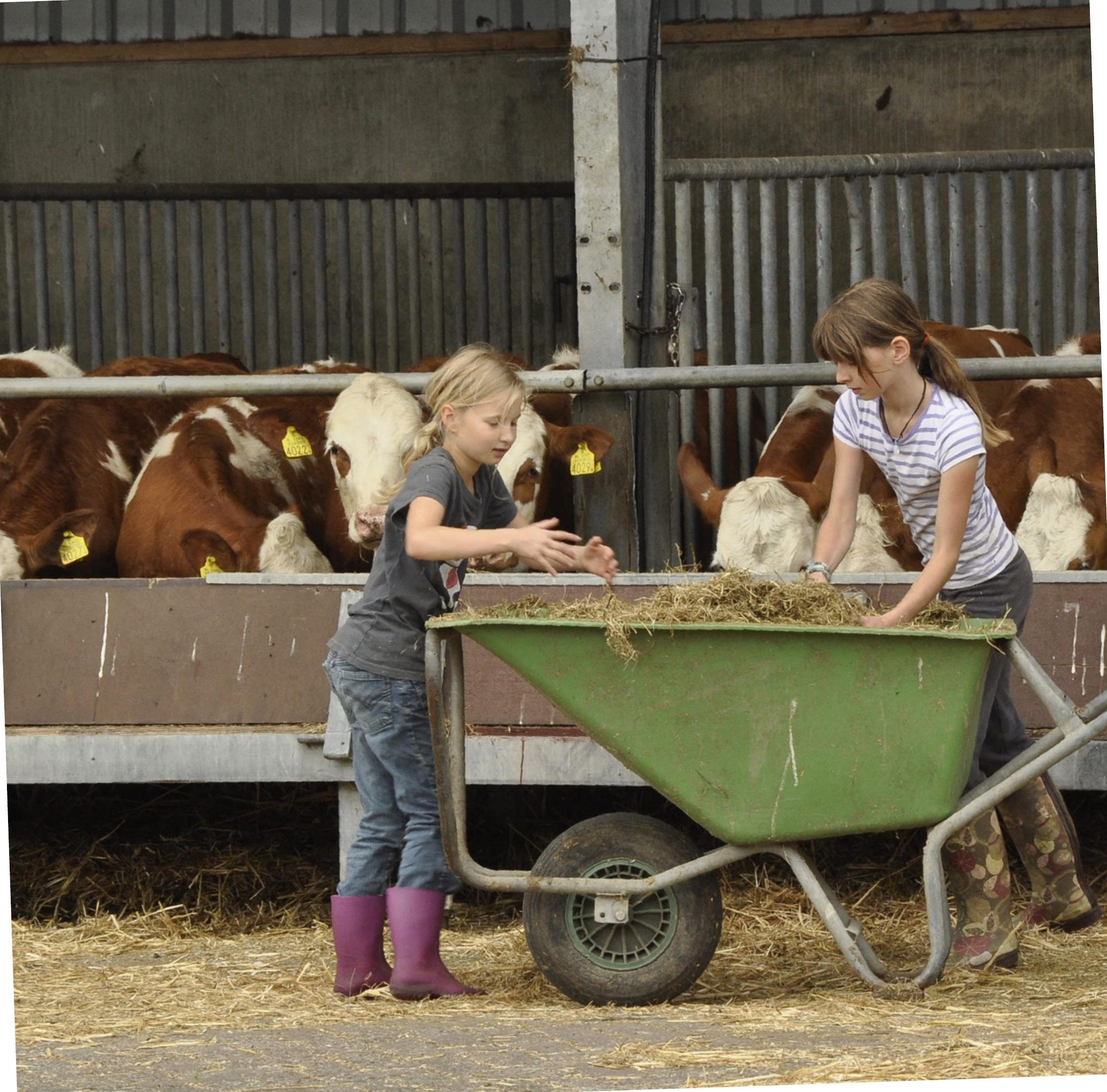




\section{Inleiding}

\section{Vraag van Stichting Omslag en zorgboerderij 't Paradijs}

Zorgboerderijen zijn bijzondere bedrijven. Een agrarische tak wordt gecombineerd met zorg. Deze boeren stellen hun bedrijf open voor kwetsbare groepen in de samenleving. Dat vraagt flink wat aanpassing en aanvullende vaardigheden. Wat bezielt deze boeren om dat te doen? Ze kiezen niet voor de gemakkelijke weg.

In de zorglandbouw is de afgelopen jaren veel veranderd. Niet alleen is het aantal bedrijven dat landbouw en zorg combineert enorm toegenomen, ook de organisatie en financiering van zorg zijn ingrijpend anders geworden. Zorgboeren en hun cliënten (in deze brochure hebben we gekozen voor het woord deelnemers, en zorgboeren kunnen zowel mannelijk als vrouwelijk zijn) hebben te maken met nieuwe regelgeving en procedures en deels nieuwe partijen met wie ze zaken moeten doen. Veel aandacht ging daarom de laatste tijd naar bureaucratie, verantwoording en financiering. Bij zowel individuele bedrijven als de sectororganisaties heeft dit de aandacht afgeleid van onderwerpen die eigenlijk wezenlijker zijn voor het bestaansrecht van zorglandbouw en de motivatie van zorgboeren.

Daarmee kan het zorgboerenbestaan, ondanks alle mensen op het erf, best eenzaam zijn. Tussen zorgboeren wordt weinig gesproken over wat hen ten diepste drijft. Stichting Omslag en zorgboerderij 't Paradijs zoeken naar manieren om het gesprek tussen zorgboeren over hun diepere drijfveren op gang te brengen. De motivatie van boeren om landbouw en zorg te combineren, de manier waarop zij omgaan met hun deelnemers en hun bedrijf vormgeven, heeft immers daarin zijn oorsprong. Omslag en 't Paradijs gaan ervan uit dat bewustwording van en gesprek over die drijfveren meerwaarde heeft voor de zorgboeren zelf, maar ook voor hun deelnemers en de bredere maatschappelijke omgeving. Om met dit gesprek een begin te kunnen maken verzochten Stichting Omslag en zorgboerderij 't Paradijs de Wetenschapswinkel van Wageningen University \& Research om een onderzoek, waarvan deze brochure een samenvatting is. 


\section{Eerder onderzoek naar waarden en drijfveren van zorgboeren}

Kwaliteiten en waarden van zorgboerderijen zijn vaker onderzocht. De meeste van die onderzoeken laten de toegevoegde waarde van zorglandbouw zien (Hassink et al 2007, Baars en Bloksma 2008, Hassink 2009, Elings et al, 2011, Hassink et al., 2011, Elings en Joop, 2013). Dit is gekeken vanuit het perspectief van deelnemers en de maatschappij: er is minder onderzoek gedaan naar het perspectief van de zorgboeren zelf. Alebeek et al (2014) doen verslag van een workshop met zorgboeren over persoonlijke waarden. Baars en Bloksma (2008) laten onder meer zeven bio-dynamische zorgboeren aan het woord over 'het wezenlijke en werkzame'. In Noorwegen is onderzoek gedaan naar motieven van zorgboeren (Fjeldavli, 2006). Wydler (2012) keek naar tevredenheid over het werk onder zorgboeren in Oostenrijk. De Moor (2016) onderzocht drie zorgboerderijen met verschillende levensbeschouwelijke uitgangspunten. Samengevat is er nog weinig zicht op diepere drijfveren en waarden van zorgboeren en is al helemaal weinig bekend over de relatie met hun praktijken.

\section{Onderzoeksvragen}

De onderzoekers zijn in overleg met de opdrachtgevers aan de slag gegaan met de volgende onderzoeksvraag:

Wat zijn de onderliggende waarden van zorgboeren en hoe beïnvloeden deze hun praktische werk?

- Welke waarden en diepere drijfveren benoemen zorgboeren?

- Hoe werken deze waarden door in de praktijk van de boerderij?

- Over welke waarden willen zorgboeren graag met anderen in gesprek?

- Hoe kunnen (deze) waarden betekenisgeving voor de individuele boer, de interactie met zorgcliënten/ deelnemers en de sector als geheel bevorderen?

- Op welke manier kan dialoog georganiseerd en gestimuleerd worden?

\section{Raamwerk en werkwijze}

In de literatuur is er niet altijd een helder onderscheid tussen motivaties, waarden en drijfveren. In deze brochure gaan wij ervan uit dat in drijfveren en waarden de grondslag voor de motivatie ligt. De diepere drijfveren worden gezien als datgene wat de boer ten diepste drijft (Roothaan, 2005).

In deze brochure gaan wij uit van een raamwerk dat gebaseerd is op het werk van Mertens en Blommestijn (2004). Zij deden kwalitatief onderzoek onder 30 agrariërs naar diepere drijfveren. Daaronder waren geen zorgboeren. De vier belangrijkste drijfveren van boeren waren volgens Mertens 
\& Blommestijn: de uitdaging om een goed en eerlijk product af te leveren; de verantwoordelijkheid voor gezin, dieren, planten, natuur, medemensen en het evenwicht in de schepping; het welbevinden in leven en werken (dat ze voelen dat het werk bij hen past); en de ervaring om door het boerenwerk dicht bij de essentie van het leven te komen.

Bij aanvang van dit onderzoek vermoedden wij dat in deze 'essentie' diepere drijfveren te vinden zijn waaruit drijfveren en waarden van 'uitdaging', 'levensstijl' en 'de ander/ de omgeving' kunnen voortkomen (zie figuur 1).

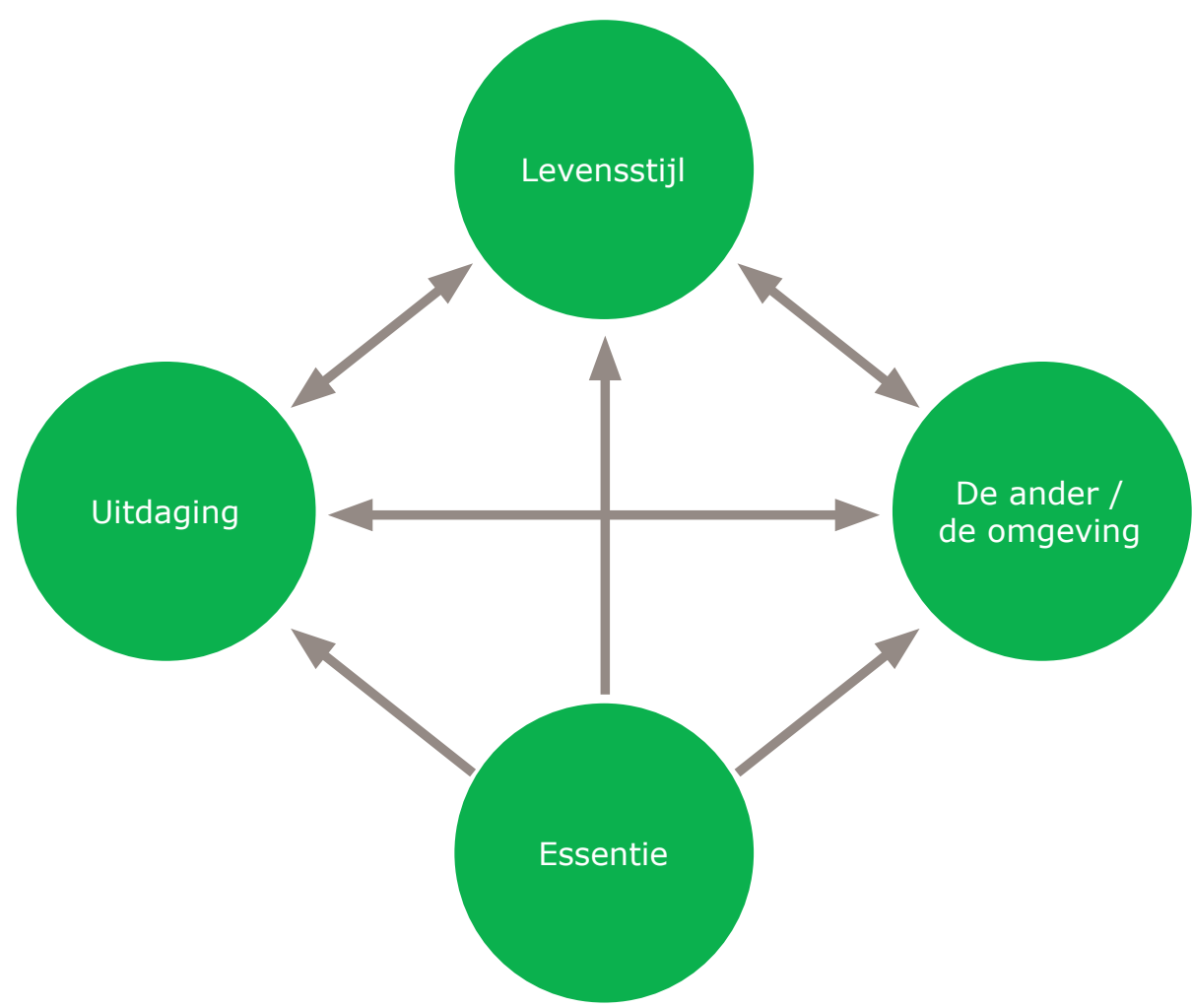

Figuur 1: Raamwerk voor drijfveren van zorgboeren o.b.v. Mertens en Blommestijn (2004) met door de onderzoekers veronderstelde samenhang

Verder gaan wij ervan uit dat praktijken ten minste voor een deel begrepen kunnen worden als uitingsvorm van diepere drijfveren en waarden (Jones et al, 2016; Westerink et al., 2018). Praktijken zien wij als routines van gedrag, inclusief taal, inrichting van de ruimte en gebruiksvoorwerpen; de 


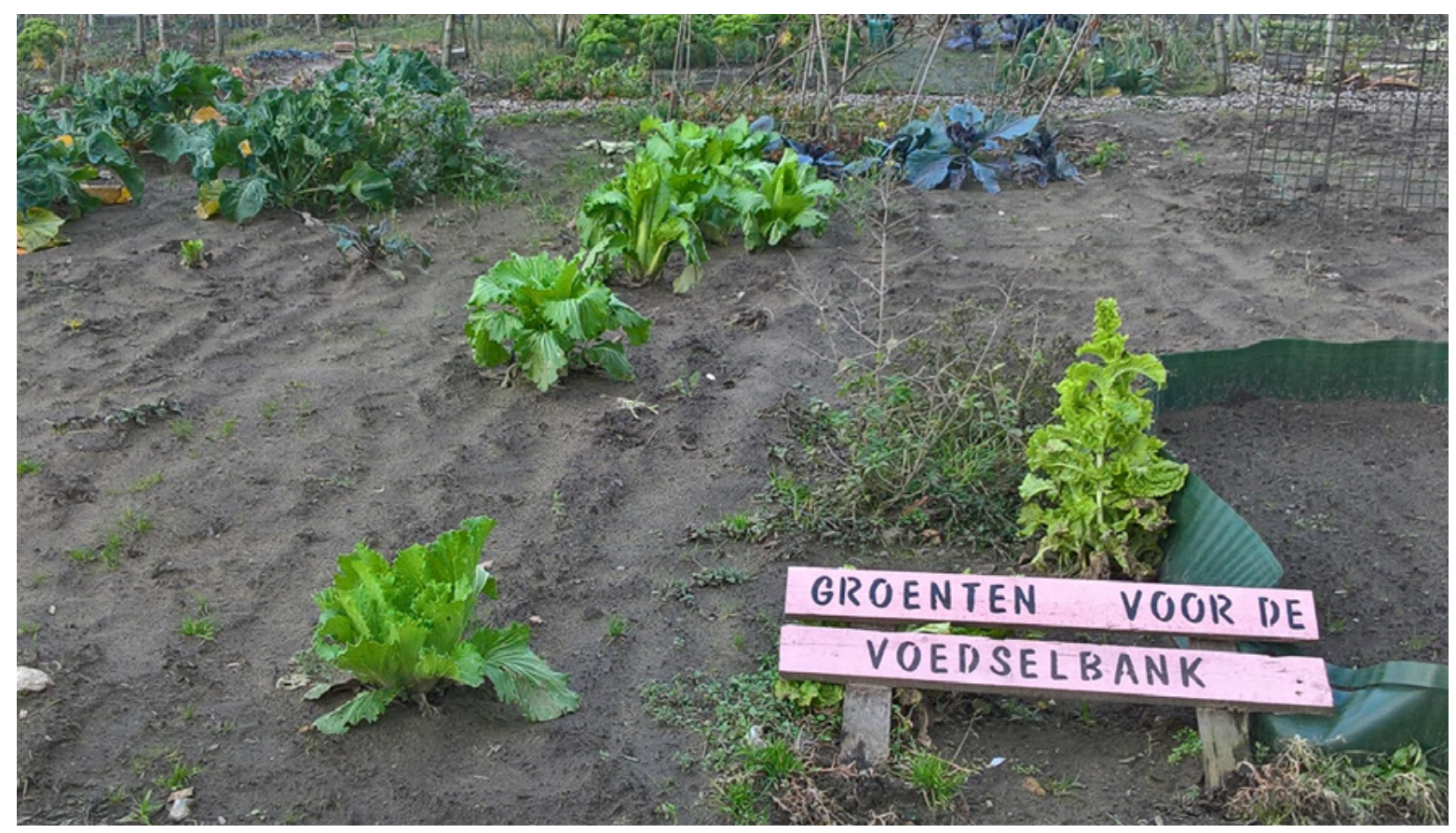

zorgboer, medewerkers en deelnemers zien wij als dragers van de praktijk van de zorgboerderij (Lamers et al., 2017).

In het onderzoek is gebruik gemaakt van kwalitatieve onderzoekmethoden. Gewerkt is met semigestructureerde vragenlijsten met een op Mertens en Blommestein (2004) gebaseerde volgorde in onderwerpen waarbij tijdens het gesprek voldoende vertrouwen kon ontstaan om de meer fundamentele onderwerpen aan te roeren. Hoogendam vulde het semi-gestructureerde interview aan met gesprek over stellingen op kaartjes. Van de interviews zijn waar mogelijk geluidsopnamen gemaakt, die woordelijk zijn uitgewerkt en samen met de aantekeningen van de observaties en losse gesprekken zijn geanalyseerd door middel van codering. De interpretatie van uitspraken naar waarden is een grote uitdaging, evenals de vergelijking van deze waarden met de ervaringen van de deelnemers, en de interpretatie van de vertaalslag tussen waarden en praktijken. Coderen van de data helpt om deze interpretaties te structureren en inzichtelijk te maken.

Deze brochure vat het werk samen van drie studenten: Sander Hoogendam (2017), Nona De KloeBouwman (2018) en Naomi Slikboer (2019). Sander en Nona hebben op in totaal tien boerderijen gegevens verzameld via interviews en participatieve observatie. Daaronder waren twee boeren die hun 
inspiratie haalden uit antroposofische of biologisch-dynamische vertrekpunten, twee zorgboeren zonder uitgesproken geloofsovertuiging, en zes christelijke zorgboeren met uiteenlopende kerkelijke achtergronden. Sander heeft de waarden en drijfveren van zorgboeren gerelateerd aan de vormgeving van de plek. Nona heeft gekeken of de waarden en drijfveren van zorgboeren herkend werden door deelnemers en medewerkers. Het werk van Sander ging vooraf aan dit Wetenschapswinkelproject. Hij gebruikte een ander raamwerk dan Nona. Naomi heeft het raamwerk van Nona gebruikt om Sanders data opnieuw te analyseren en te zoeken naar de relatie tussen waarden/ drijfveren en praktijken.

Nona en Naomi hebben beiden gebruik gemaakt van de vier categorieën van Mertens en Blommestijn in hun zoektocht naar drijfveren en waarden van zorgboeren. Nona heeft door literatuurstudie en bottom-up coderen diverse drijfveren en waarden van zorgboeren in dit raamwerk ondergebracht. Naomi heeft deze verder doorontwikkeld door het analyseren van de data van Sander. Voor een uitgebreider conceptueel raamwerk van waarden kunt u verder lezen in de scriptie van Nona (De Kloe-Bouwman, 2018). Naomi heeft in haar scriptie het uiteindelijke overzicht van drijfveren, waarden en praktijken opgenomen (Slikboer, 2019: bijlage aangepast codeboek). 


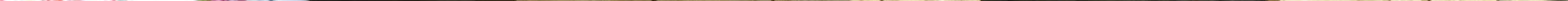




\section{Waarden en drijfveren in de case studies}

Op basis van ons onderzoek komen we tot een indeling van drijfveren en waarden van zorgboeren (zie figuur 2). Uiteraard zijn andere indelingen mogelijk. Op de gespreksdag met zorgboeren in maart 2019 was onder de deelnemers herkenning van de indeling die we hebben gemaakt en de woorden die we daarvoor hadden gekozen. We lichten de drijfveren en waarden kort toe.

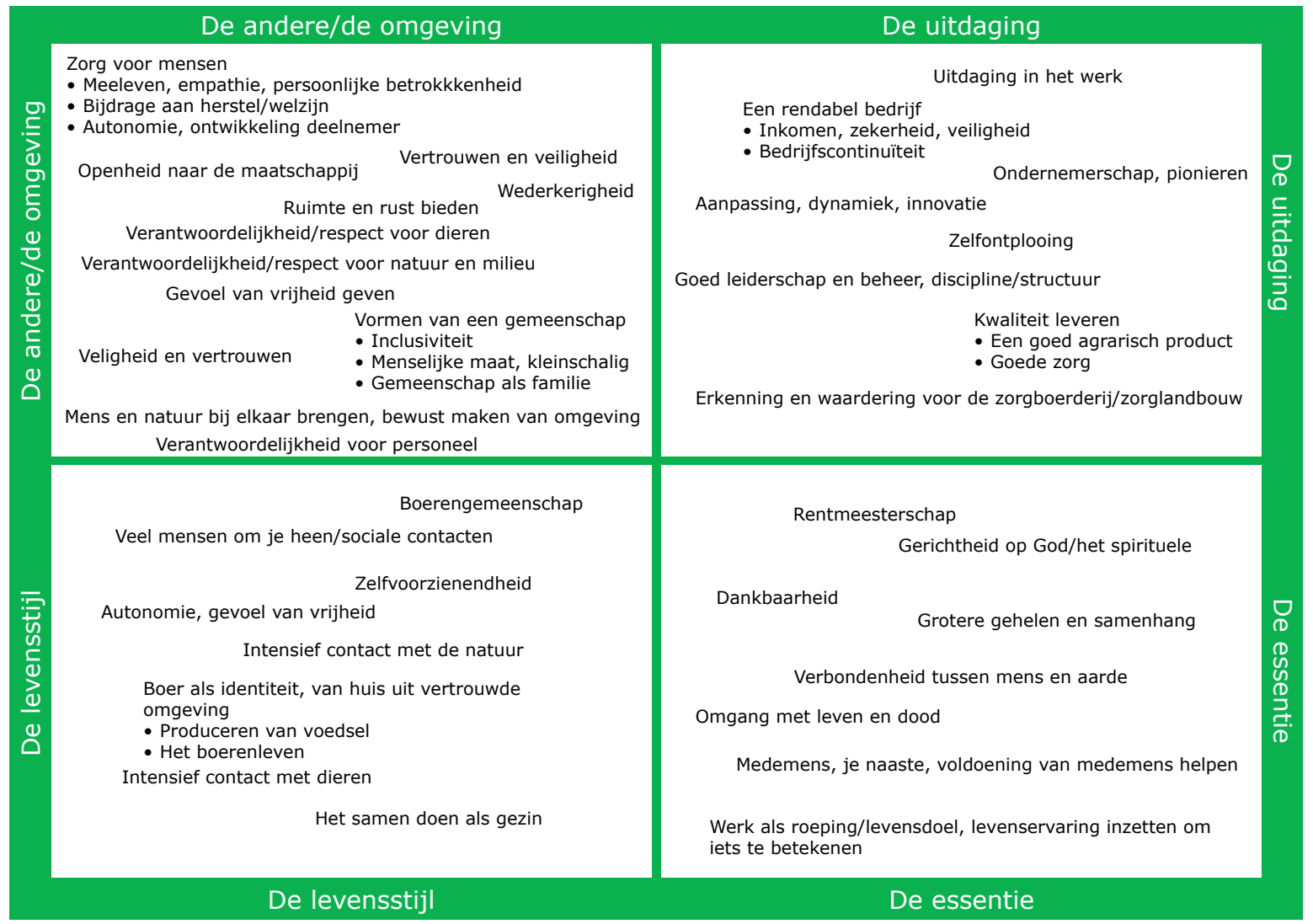

Figuur 2: Indeling van drijfveren en waarden van zorgboeren 


\section{De Ander/ de Omgeving (horizontale verbinding)}

De drijfveren en waarden van zorgboeren in de categorie De Ander/ de Omgeving betreffen een gevoel van verantwoordelijkheid voor andere mensen en voor de natuur, het land, de dieren en de plek. Ze hangen nauw samen met betrokkenheid en een behoefte om te zorgen. Deze drijfveren en waarden gaan uit van een relatie.

- Verantwoordelijkheid/respect voor natuur en milieu: je gaat als zorgboer zorgvuldig om met natuur en milieu en maakt de wereld wat dat betreft het liefst een beetje beter. Natuur is immers een belangrijk onderdeel van het bedrijf.

- Verantwoordelijkheid/respect voor dieren: je bent als zorgboer verantwoordelijk voor je dieren, daar zorg je goed voor.

- Openheid naar de maatschappij: je hebt als zorgboerderij iets te bieden aan de samenleving, mensen zijn welkom om deel te worden van de boerderijgemeenschap.

- Zorg voor mensen: je bent als zorgboer persoonlijk betrokken bij je deelnemers. Je toont medeleven en empathie. Je wilt bijdragen aan hun herstel en welzijn. Uiteindelijk is de zorg gericht op de ontwikkeling van de deelnemers en versterking van hun autonomie. Je wilt hen zingeving bieden: ze mogen er zijn en kunnen iets bijdragen.

- Gelijkwaardigheid, respect: jij en je deelnemers zijn gelijkwaardig, je gaat respectvol met hen om.

- Wederkerigheid: $j i j$ hebt iets te bieden aan je deelnemers, en zij hebben jou iets te bieden.

- Het vormen van een gemeenschap: de zorgboer en zijn of haar gezin vormen met de medewerkers en de deelnemers een gemeenschap. Iedereen hoort erbij en helpt elkaar. Er wordt gestreefd naar verbondenheid. Het is bijna een soort familie. Daardoor heeft de zorg menselijke maat. De kleinschaligheid biedt geborgenheid en veiligheid.

- Veiligheid en vertrouwen: het is belangrijk dat deelnemers zich veilig voelen en de boer, de medewerkers en de andere deelnemers kunnen vertrouwen.

- Ruimte en rust bieden: op de zorgboerderij is er rust en ruimte. Dit heeft ook alles te maken met het buiten zijn en het werk op de boerderij. Je biedt als zorgboer graag rust en ruimte aan de deelnemers vanuit de overtuiging dat dit hen goed zal doen.

- Gevoel van vrijheid: deelnemers moeten zichzelf kunnen zijn en zich vrij voelen om zich op hun manier te uiten.

- Mens en natuur bij elkaar brengen: op de boerderij komen deelnemers vanzelf in contact met de natuur. Dit helpt deelnemers om zich bewust te worden van de omgeving en van levensprocessen.

- Verantwoordelijkheid voor personeel: als zorgboer zorg je goed voor je personeel en ondersteun je hen in hun werk en hun ontwikkeling. Het is belangrijk om een team met hen te vormen. 


\section{De Uitdaging (voor jezelf)}

Drijfveren en waarden in de categorie De Uitdaging gaan over de verschillende manieren waarop de zorgboer uitdaging zoekt in het werk. Deze waarden hebben te maken met ondernemerschap, zelfontplooiing en kwaliteit.

- Een rendabel bedrijf: je bedrijf is de bron van inkomsten. Een rendabel bedrijf is misschien niet het allerbelangrijkste, maar is een randvoorwaarde om de andere dingen die je belangrijk vindt vorm te kunnen geven. Als het bedrijf goed draait, is dat wel iets om trots op te zijn. Je wilt ook graag dat het bedrijf kan worden voortgezet. Als er financiële zekerheid is, geeft dat ook rust.

- Kwaliteit leveren: je wilt als zorgboer kwaliteit leveren als het gaat om een goed agrarisch product, en je wilt goede zorg leveren. Wat goede zorg is, daar heb je wel een eigen mening over.

- Erkenning en waardering voor de zorgboerderij: je vindt het belangrijk om erkenning en waardering te krijgen voor wat je doet en voor de meerwaarde van zorglandbouw ten opzichte van andere vormen van zorg.

- Goed leiderschap en beheer: je wilt goed leiding geven aan je team en hen en je deelnemers een goede structuur bieden die rust en veiligheid schept.

- Uitdaging in het werk: je zoekt uitdaging in de afwisseling en de complexiteit van het werk als zorgboer. Het is niet de bedoeling dat het routine wordt.

- Zelfontplooiing: je wilt jezelf blijven ontwikkelen en je talenten gebruiken.

- Ondernemerschap, pionieren en innovatie: je wilt nieuwe dingen blijven doen, je bedrijf blijven aanpassen en ontwikkelen.

\section{De Levensstijl (dynamische verbinding)}

Waarden en drijfveren binnen De Levensstijl drukken uit dat het bij zorgboer zijn om een manier van leven gaat. Het is een veelzijdige, avontuurlijke manier van leven die intensief contact met natuur en dieren combineert met veel contact met mensen.

- Boer als identiteit: boer zijn is geen beroep, het is een manier van zijn. Het boerenleven, het voortbrengen van voedsel, dat maakt deel uit van wie je bent, vaak al van jongs af aan. Je wilt jezelf graag kunnen zien als goede (zorg-)boer.

- Zelfvoorzienendheid: je leeft van het land en je probeert zoveel mogelijk van wat je op je bedrijf tot je beschikking hebt tot waarde te brengen door de verschillende onderdelen elkaar te laten versterken.

- Autonomie, gevoel van vrijheid: je bent eigen baas, je kunt het op jouw manier doen.

- Het samen doen als gezin: je werkt waar je woont en je doet de zorgboerderij zoveel mogelijk 
samen met je partner, je ouders en/ of je kinderen. Het liefst geef je het bedrijf door aan de volgende generatie.

- Veel mensen om je heen: je geniet ervan om veel mensen om je heen te hebben. Je vindt het bouwen en onderhouden van sociale contacten belangrijk.

- Boerengemeenschap: je hecht belang aan wat andere (zorg-)boeren van je vinden. Je voelt je verbonden met andere (zorg-)boeren en je identificeert je meer met hen dan met anderen.

- Intensief contact met de natuur en met dieren: intensief contact met de natuur en met dieren is voor jou een belangrijk deel van plezier in het werk.

\section{De Essentie (verticale verbinding)}

De Essentie vat diepere drijfveren samen die te maken hebben met de essentie van het leven: het onderdeel uitmaken van een groter geheel, zingeving, levensbeschouwing en geloof. Op de zorgboerderij ben je dag in dag uit bezig met leven en dood en vaak ook met diepe levensvragen van deelnemers en van jezelf. Voor veel zorgboeren liggen de drijfveren in de Essentie nog dieper dan die van De Ander/ de Omgeving, De Uitdaging en De Levensstijl.

- Gerichtheid op God, het spirituele: je bekijkt jezelf en je bedrijf vanuit je relatie met God. Je staat er niet alleen voor. God, of het spirituele, is de bron waaruit je leeft.

- Rentmeesterschap: je gaat ervanuit dat je alles wat je hebt, inclusief je bedrijf, in bruikleen hebt. Dat schept een speciale verantwoordelijkheid voor mensen en natuur.

- Dankbaarheid: je bent dankbaar voor alles wat je hebt ontvangen en hebt de behoefte om daarvan uit te delen. Je bent dankbaar voor wat je mag doen.

- Omgang met leven en dood: door dagelijks bezig te zijn met leven en dood leer je dingen accepteren en word je je bewust van levensprocessen en van de waarde van je eigen leven. Dat geef je je deelnemers graag mee.

- Grotere gehelen en samenhang: je bent ervan overtuigd dat de deelnemers meer in contact komen met zichzelf als zij op de zorgboerderij kunnen ervaren dat zij onderdeel zijn van het grotere geheel, en zich kunnen verwonderen over de samenhang in de natuur.

- Werk als roeping of levensdoel: je voelt dat je als zorgboer een speciale taak hebt in dit leven. Je mag je levenservaringen inzetten om iets te betekenen voor een ander.

- Medemens als levensbestemming: je voelt op een spiritueel niveau dat je tot je bestemming komt door het helpen van je medemensen. Je doet daarmee wat God van je vraagt. 


\section{Relaties tussen drijfveren en waarden}

Per persoon verschilt welke drijfveren en waarden de boventoon voeren en wat ze precies betekenen. Zo betekent gelijkwaardigheid op de ene zorgboerderij dat de zorgboer geen vaste dagstructuur aan zijn deelnemers wil opleggen. Op een andere zorgboerderij betekent dit dat de deelnemer op de hoogte is van alle afspraken met betrekking tot de zorg. En op een derde bedrijf dat de deelnemers ook dingen moeten doen die ze niet leuk vinden.

Uit de analyse van Naomi Slikboer blijkt, dat de respondenten zelf allerlei verbanden leggen tussen hun drijfveren en waarden. Ook welke verbanden worden gelegd, verschilt per persoon. Zo kan kleinschaligheid belangrijk zijn om de deelnemers vrijheid te bieden. Of het bieden van zingeving kan volgens een zorgboer ruimte scheppen voor vrijheid. Of het gevoel van vrijheid bij de deelnemers kan versterkt

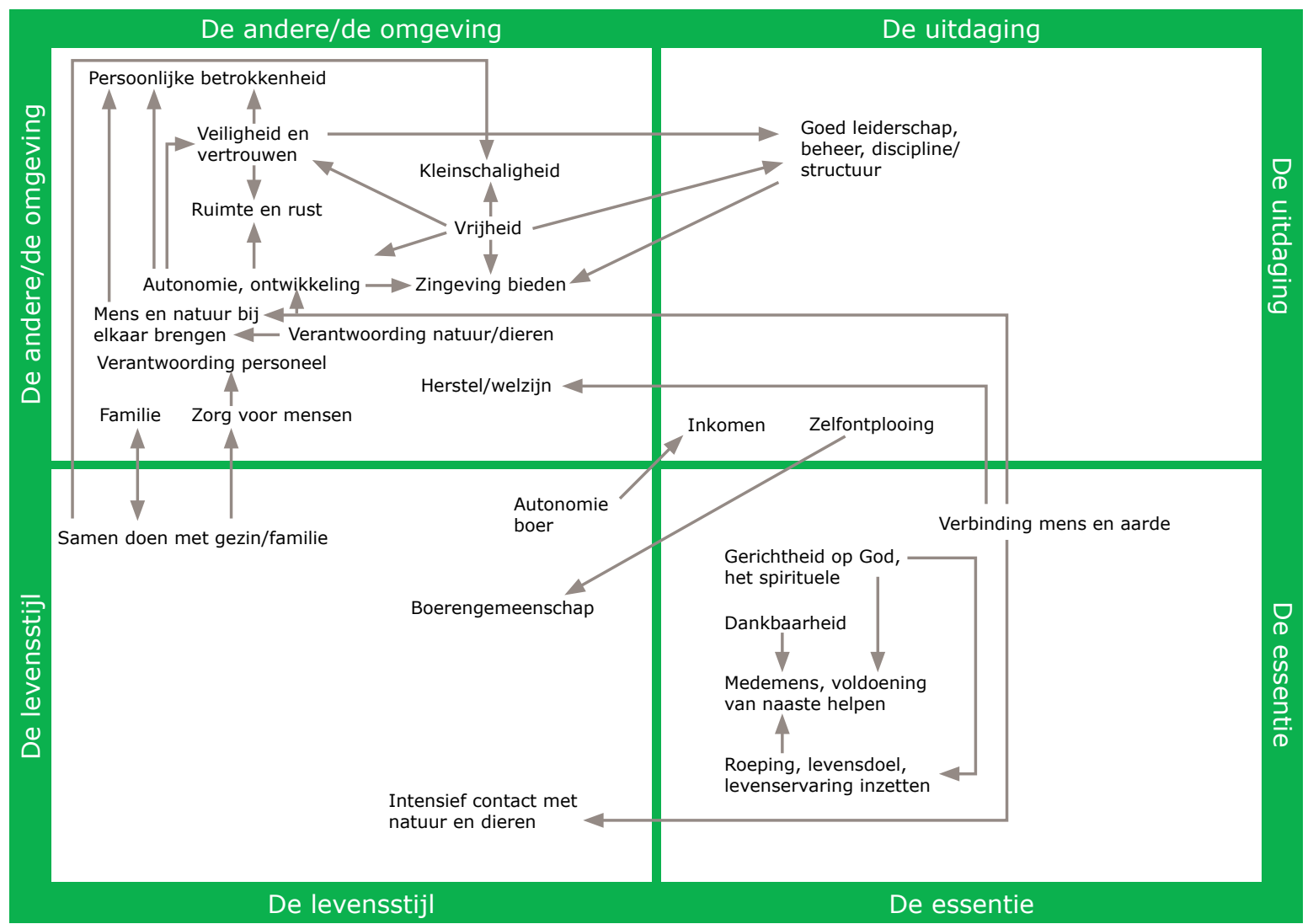

Figuur 3: Relaties tussen drijfveren en waarden die zorgboeren zien 


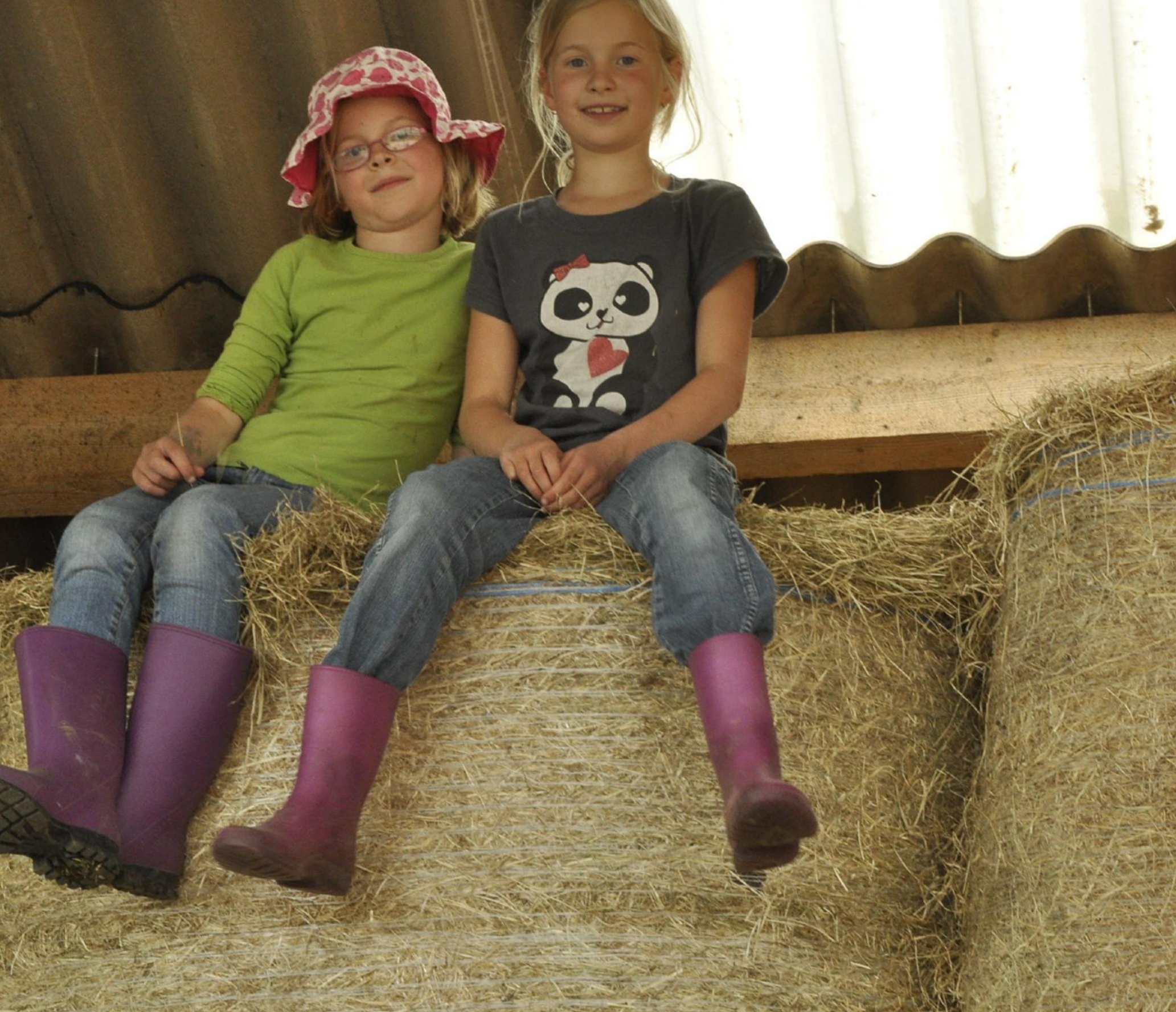


worden door het bieden van veiligheid, vertrouwen en ruimte voor autonomie. Figuur 3 laat een aantal van dergelijke positieve verbanden zien, zowel binnen als tussen categorieën. Hierin valt op, dat de Essentie inderdaad een bron is voor diverse andere drijfveren en waarden. Er lopen namelijk geen pijlen van de andere categorieën naar de Essentie.

Het kan echter ook wringen tussen drijfveren en waarden. Zo kan het belang van zoveel mogelijk aandacht geven aan en klaar staan voor deelnemers botsen met de eigen autonomie of de aandacht voor het eigen gezin. Of de structuur en discipline die rust en veiligheid biedt aan de ene deelnemer, kan de vrijheid van de andere deelnemer beknotten. Iemand anders zal juist weer zeggen dat structuur nodig is om vrijheid te kunnen geven. Iedere zorgboer zal hier andere accenten in leggen.

\section{Drijfveren en waarden in de praktijk}

In de rapporten van Hoogendam, De Kloe en Slikboer wordt uitgebreid ingegaan op de bedrijven, hun praktijken, en de waarden en drijfveren die zijn benoemd. Hier beperken wij ons tot enkele voorbeelden. Deze voorbeelden zijn niet representatief: verschillende zorgboeren leggen de nadruk op verschillende waarden en maken ook andere keuzes in de praktijk.

\section{Hoe de boeren dat zien}

Voor veel van de benoemde drijfveren en waarden geven de zorgboeren ook voorbeelden van hoe zij die in de praktijk brengen. Openheid naar de samenleving kan bijvoorbeeld worden vormgegeven door middel van een boerderijwinkel, het onderhoud doen van een sportpark, of door op de boerderij ruimte te bieden aan een carnavalsvereniging. Persoonlijke betrokkenheid kan tot uitdrukking komen door te vragen hoe het weekend was, en de activiteiten af te stemmen op wat de deelnemer nodig heeft. Deelnemers kunnen geholpen worden om zelfstandiger te worden door hen dingen te laten doen die ze eigenlijk een beetje eng vinden. Het geven van verantwoordelijkheid aan deelnemers, bijvoorbeeld door hen dieren te laten voeren, is een manier om hen zingeving te laten ervaren.

Het invullen van zoveel mogelijk taken met familie- en gezinsleden is een manier om zowel veel met de familie samen te kunnen doen, als om een familie-omgeving te creëren voor de deelnemers. De drijfveer autonomie en de ambitie om goede zorg te leveren, kunnen ertoe leiden dat wordt afgeweken van de formele regels ten aanzien van zorg, omdat de zorgboer ervan overtuigd is dat zijn of haar aanpak beter past bij wat de deelnemer op dat moment nodig heeft. Het opzetten van de zorgboerderij was voor diverse zorgboeren een uiting van de drijfveren ondernemerschap en pionieren, soms in combinatie van de ervaring geroepen te zijn tot deze stap. 
In diverse gesprekken werden bepaalde drijfveren niet benoemd, maar benoemde de boer wel bepaalde praktijken die erop kunnen duiden dat die drijfveer wel belangrijk is. Zo is 'persoonlijke aandacht geven' niet altijd genoemd als drijfveer, maar leek dat wel een rol te spelen in de praktijk van de zorgboerderij. Mogelijk zijn dergelijke waarden zo vanzelfsprekend, dat ze niet worden genoemd. Het vragen naar praktijken kan blijkbaar een aanvullende manier zijn om over waarden en drijfveren in gesprek te komen.

Er zijn ook waarden en drijfveren genoemd waarvan er door de onderzoeker bij de analyse van het gesprek geen vertaling naar de praktijk gevonden kon worden. Niet alle boeren brengen bijvoorbeeld onder woorden hoe ze 'vertrouwen' in de praktijk vormgeven. Wel is duidelijk dat de relatie tussen de zorgboer en de deelnemer daarvoor belangrijk is. In verband met de waarde 'zorg voor het milieu' legt een zorgboer uit dat die voor hem lastig in de praktijk te brengen is in de vorm van biologische teelt, omdat hij daar vooralsnog een botsing ziet met de waarde van het leveren van een goed product. De drijfveren die door de zorgboeren het lastigst te vertalen zijn in praktijkvoorbeelden, zijn die in de Essentie. Wellicht heeft het er mee te maken dat drijfveren in De Essentie vooral ten grondslag liggen aan andere drijfveren en waarden.

\section{Wat deelnemers en medewerkers herkennen}

Deelnemers en medewerkers benoemen diverse aspecten die de zorgboer volgens hen belangrijk vindt. Nona de Kloe concludeert dat er sprake is van herkenning van diepere drijfveren door deelnemers en medewerkers, en ziet daarin ook een bevestiging van relaties tussen wat de zorgboer belangrijk vindt en hoe dat in de praktijk tot uitdrukking komt. Deze herkenning was niet bij alle deelnemers en op alle bedrijven even groot. Dat kan te maken hebben met de beperkte mogelijkheden tot abstractie en reflectie bij sommige deelnemers met een beperking. Het kan ook te maken hebben met de organisatievorm en omvang van de boerderij en de mate van direct contact tussen zorgboer en deelnemers. Dit laat zien dat het contact tussen zorgboer en deelnemers belangrijk is voor het overdragen en in de praktijk brengen van waarden.

\section{Vormgeving van de plek}

Het onderzoek van Sander Hoogendam laat zien dat drijfveren en waarden tot uiting kunnen komen in de vormgeving van de plek van de boerderij. Zo kan de waarde 'verantwoordelijkheid/ respect voor dieren' tot uitdrukking komen in een keuze voor vrije uitloop van de kippen. Dit is zichtbaar in de inrichting van de boerderij. Een ander voorbeeld is de vertaling van de drijfveren 'verbondenheid met de aarde' en 'verbondenheid met elkaar' in de keuze voor handwerk en een kleinschalige opzet. Sommige zorgboerderijen hebben een bezinningstuin of een andere plek die ruimte geeft aan gerichtheid op God of het spirituele. 



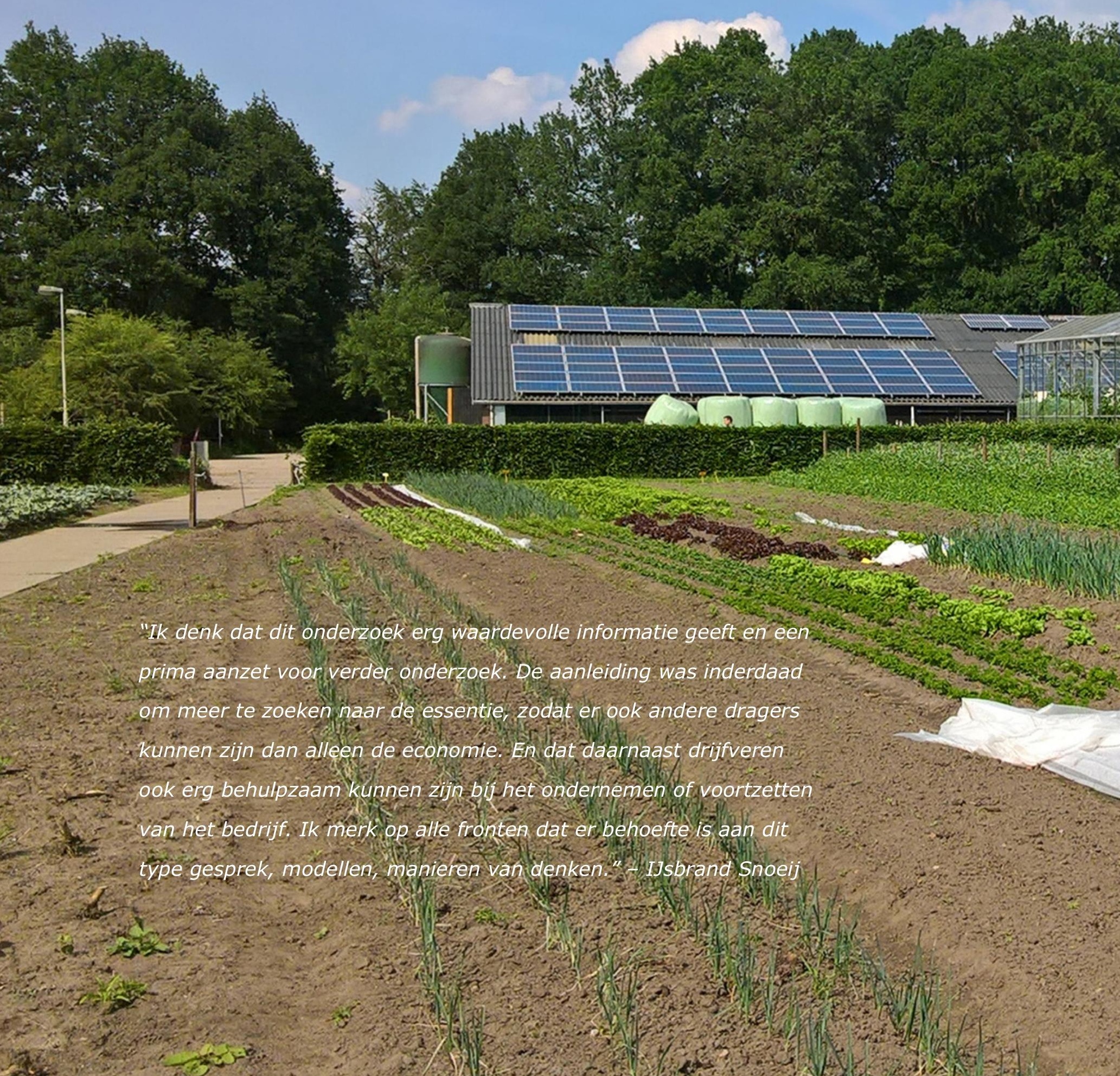




\section{Praten over drijfveren en waarden}

Zorgboeren vinden het nog best moeilijk om hun diepere drijfveren en waarden onder woorden te brengen en voorbeelden te geven van hoe deze in de praktijk tot uitdrukking komen (zie ook Alebeek et al 2014). Toch zijn heel mooie gesprekken gevoerd. De meesten voeren dit soort gesprekken niet zo vaak. Vooral de drijfveren in De Essentie waren voor verschillende respondenten lastig om over te vertellen. In het onderzoek ontstond de indruk dat de boeren met een christelijke of een antroposofische levensovertuiging gemakkelijker praatten over De Essentie. Mogelijk zijn zij meer gewend om daarover na te denken en daar ook woorden aan te geven.

Zorgboeren verschillen in de nadruk die ze leggen op bepaalde drijfveren en waarden. Daardoor geven ze verschillend invulling aan hun eigen kwaliteitsstandaard. Zo ontstaat op elke zorgboerderij een eigen identiteit door de unieke combinatie van aspecten waar de nadruk op gelegd wordt. Hiermee onderscheiden de zorgboerderijen zich van elkaar en kunnen ze gezamenlijk een breed palet van zorg bieden, en is er voor een breed scala aan deelnemers een passende plek. Dit hoeft niet te betekenen dat andere aspecten door de boeren als onbelangrijk worden beschouwd; hoogstens dat daar in vergelijking met andere zorgboeren minder de nadruk op gelegd wordt.

Ook is duidelijk dat deelnemers wel degelijk uit woorden en gedrag oppikken wat voor de zorgboer belangrijk is. De praktijken op de zorgboerderij dragen bij aan zingeving, zowel voor de zorgboer als voor de medewerkers en deelnemers. De resultaten van het onderzoek nodigen uit om als zorgboer open te spreken over je drijfveren en waarden met je medewerkers en deelnemers en om daar nog bewuster uitdrukking aan te geven in je praktijken en in je communicatie met partners, zoals de gemeente.

De rijkdom aan visies en praktijken kan onder zorgboeren een bron vormen van bewustwording, onderling leren en nieuwe inspiratie. Zowel de interviews als de gespreksdag bevestigden dat het zeer de moeite waard is om als zorgboeren met elkaar en met anderen te praten over wat je ten diepste drijft.

Als onderzoekers hopen we dat dit onderzoek bijdraagt aan de voortzetting van dat gesprek. Stichting Omslag en 't Paradijs zijn inmiddels al begonnen met het uitdragen en bespreken van de onderzoeksresultaten onder zorgboeren. 


\section{Literatuur}

Alebeek, F. van, B. Smit, O. van der Valk \& D. de Jong, 2014. Workshop Werken met Waarden. Wat zijn de kernwaarden van mijn bedrijf en hoe passen die bij mijn verdienmodel? Beknopt verslag van de workshop op 21 november 2014 te Woudenberg. Wageningen UR, LEI \& PPO-AGV.

Baars, E.W., J.R. Bloksma. 2008. Verschuivende paradigma's binnen Landbouw \& Zorg: Zorg voor gehelen en samenhangen. Rapport M30. Louis Bolk Instituut, Driebergen. $25 \mathrm{p}$

De Kloe-Bouwman, N., 2018. Zorgboer, wat bezielt je? Een onderzoek naar diepere drijfveren en herkenning in de praktijk. Kwalitatief explorerend onderzoek op vier zorgboerderijen in Nederland. Wageningen University, MSc Thesis Knowledge, Technology \& Innovation CPT-80833.

Elings, M., Haubenhofer, D., Hassink, J., Rietberg, P., \& Michon, H. (2011) Effecten van zorgboerderijen en andere dagbestedingsprojecten voor mensen met een psychiatrische en verslavingsachtergrond. Rapport 376. Plant Research International, Wageningen University \& Research. Stichting Dienst Landbouwkundig Onderzoek. Trimbos Instituut.

Elings, M., \& Joop, W., 2013. Landbouw \& Zorg: Lessen over zorglandbouw. Wageningen: PPO-PRI.

Moor, de, A.C.K., 2016. Zorgboerderijen in Nederland. Modern geluk in een traditionele context. Masterscriptie Religiewetenschappen, specialisatie Religiestudie. Radboud University Nijmegen.

Fjeldavli, E., 2006. The lay beliefs about farming for health. In: Hassink, Jan, en Majken Van Dijk (Eds.), 2006. Farming for Health: Green-care farming across Europe and the United States of America. Chapter 6, pp. 73-90. Vol. 13. Springer Science \& Business Media.

Hassink, J., C. Zwarbol, H. Agricola, M. Elings \& J. Thissen, 2007. Current status and potential of care farms in the Netherlands. NJAS - Wageningen Journal of Life Sciences, 55(1), pp. 21-36

Hassink, J. (2009). Zorgboerderijen dragen bij aan empowerment en eigen kracht van deelnemers. Wageningen: Plant Research International. Rapport nr. 299 
Hassink, J., A. van Dijk en D. Klein Bramel, 2011. Waarden van landbouw en zorg. Wageningen: Plant Research International. Rapport Nr. 369.

Hoogendam, S., 2017. Persoonlijke Waarden van Zorgboeren en de Uitwerking op de Vormgeving van de Boerderij en de Praktijk. Wageningen University, MSc thesis Rural Sociology RSO-80436.

Jones, N. A., Shaw, S., Ross, H., Witt, K., \& Pinner, B., 2016. The study of human values in understanding and managing social-ecological systems. Ecology and Society, 21(1).

Lamers, M., R. Van der Duim \& G. Spaargaren, 2017. The relevance of practice theories for tourism research. Anals of Tourism Research, 62, pp. 54-63

Mertens, F. en H. Blommestijn, 2004. Boer in hart en ziel. Zoektocht naar de diepere drijfveren van agrariërs. Wageningen: Stichting Vrienden van het Platteland.

Roothaan, A., 2005. Terugkeer naar de natuur. De betekenis van natuurervaring voor een nieuwe ethiek. Kampen: Klement

Slikboer, N., 2019. Zin in zorglandbouw: hoe waarden en diepere drijfveren zich vertalen in de praktijk. Wageningen University, stagerapport Leisure, Tourism \& Environment.

Westerink, J., Smit, A.B., Dijkshoorn-Dekker, M.W.C., Polman, N.B.P., \& Vogelzang, T.A., 2018. Boeren in Beweging. Hoe boeren afwegingen maken over natuurinclusieve landbouw en hoe anderen hen kunnen helpen. Wageningen: Wageningen Environmental Research.

Wydler, H., 2012. Arbeitszufriedenheit aus Diversifikationsstrategien - das Beispiel Care Farming [Work Satisfaction in Farm Diversification Strategies - the Case of Care Farming]. Jahrbuch der Österreichischen Gesellschaft für Agrarökonomie, Band 21(2): 155-164. 
28 | Zin in landbouw en zorg 



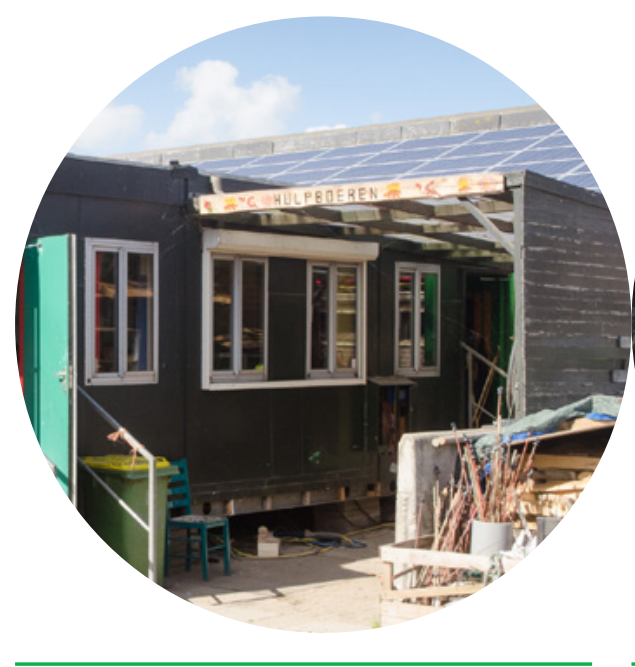

Wageningen University \& Research Wetenschapswinkel

Postbus 9101

$6700 \mathrm{HB}$ Wageningen

T (0317) 483908

E wetenschapswinkel@wur.nl

www.wur.nl/wetenschapswinkel

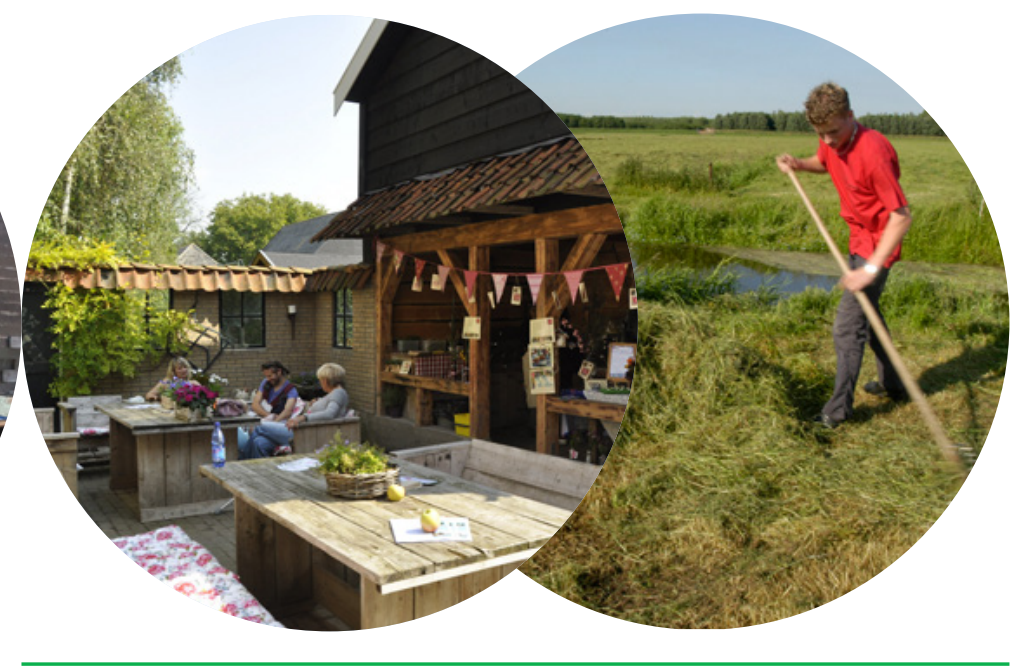

Maatschappelijke organisaties zoals verenigingen en belangengroepen, die niet over voldoende financiële middelen beschikken, kunnen met onderzoeksvragen terecht bij de Wetenschapswinkel van Wageningen University \& Research. Deze biedt ondersteuning bij de realisatie van onderzoeksprojecten. Aanvragen moeten aansluiten bij de werkgebieden van Wageningen University \& Research: duurzame landbouw, voeding en gezondheid, een leefbare groene ruimte en maatschappelijke veranderingsprocessen.

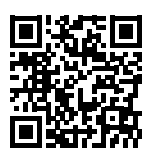

